Bangl. J. Vet. Med. (2009). 7(2): 304-312

\title{
DETERMINATION OF IN-VIVO GROWTH KINETICS OF VIRULENT NEWCASTLE DISEASE VIRUS IN BROILER CHICKENS
}

\author{
M. J. Ara ${ }^{1}$, M. T. Islam ${ }^{1,2}$, M. T. Hossain ${ }^{1}$, M. A. Haque ${ }^{1}$, R. Ahmed ${ }^{3}$, M. M. I. Chowdhury ${ }^{1}$, M. M. Kamal ${ }^{1}$, \\ A. Akter ${ }^{1}$ and M. A. Islam ${ }^{1 *}$ \\ ${ }^{1}$ Department of Microbiology and Hygiene, ${ }^{2}$ Department of Medicine, Faculty of Veterinary Science, \\ ${ }^{3}$ Department of Biotechnology, Faculty of Agriculture, Bangladesh Agricultural University, \\ Mymensingh-2202, Bangladesh
}

\begin{abstract}
The research work was conducted on 105 broiler chicks (Cobb-500) with a view to determine the rate of distribution of Newcastle disease virus (NDV) in various organs following infection through natural (intranasal, intraocular and oral) and parenteral (intravenous, intramuscular and subcutaneous) routes of inoculation at different ages (7, 15 and 28 days of old). Each bird received a dose of $0.2 \mathrm{ml}$ of NVNDV $\left(300 \mathrm{ELD}_{50}\right)$. Body temperature, onset of clinical signs and mortality of birds (if any) were recorded daily. Blood samples were collected from the birds to determine the serum HI titre before and after infection. Faeces and various tissue samples (brain, lungs, kidney, colon, bursa of Fabricius, spleen and thymus) were collected daily following post-mortem examination of one bird from each sub-group to determine the presence of NDV along with their HA titre through inoculation into embryonated hen eggs. Some representative samples were also inoculated into chicken embryo fibroblast (CEF) cell culture for isolation of NDV. The highest body temperature $\left(\geq 108^{0} \mathrm{~F}\right)$ was recorded in the birds of almost all the experimental groups between 48 and 72 hours of PI. Appearance of clinical sings was observed earlier (between 48 to 72 hours of PI) in parenterally infected birds than those of inoculated through natural routes. The shortest duration ( $>26-$ 54 hours of PI) and longest duration (67-132 hours of PI) of death time recorded in birds those were inoculated through IV and oral routes of infection respectively. Isolation of NDV was positive from day 2 of PI and onward in all the groups with some minor variations in some cases. The CEF cell culture system was found more sensitive compared to avian embryo. Irrespective of routes of inoculation and age of birds, there was significant $(p<0.01)$ increase in the mean HA titre of NDV with the progression of time. The highest HA titre of NDV was found in the brain tissue followed by lungs and kidney. Significantly $(p<0.01)$ higher HA titre of NDV isolate was recorded in the birds of all the experimental groups inoculated through IV route. Following infection, the MDA titres decreased day by day in the birds with the increase of HA titres of NDV.
\end{abstract}

Key words : Growth kinetics, Newcastle disease virus, HA titre, MDA, broiler chickens

\section{INTRODUCTION}

Among the poultry viral diseases, Newcastle disease (ND) has been classified as a list "A" disease by the Office International des Epizooties (OIE) because of its high contagiousness and resulting high morbidity and mortality in susceptible birds (Liu et al., 2006). The ND is caused by an enveloped, negative-sense, single-stranded RNA virus i.e. Newcastle disease virus (NDV) of the genus Rubulavirus under the family Paramyxoviridae (Alexander, 1997 and Lamb et al., 2000). According to the strain variation, the rate of morbidity and mortality of poultry in a flock due to ND varies from $90-100 \%$ and for this reason, poultry industry all over the world faces serious economic losses every year (Awan et al., 1994 and Gutierrez-Ruiz et al., 2000).

The growth kinetics of NDV may be the way of distribution of this virus in different systems after infection. As NDV is a multisystemic virus, it travels the host's body to affect the target organs like brain, lungs, kidney etc. In early stage of the infection, it is not possible to isolate the virus from all the organs which will depend on the pathotypes of NDV. The neurotropic virulent NDV mainly affects the nervous and respiratory system (Wilczynski et al., 1977), but this strain may also be isolated from lymphoid and digestive system (Haque, 2007 and Babu, 2007). NDV causes death of birds infecting single or multiple organs. After introduction of NDV into the body, the rate of distribution throughout the body may be slow, moderate or faster depending on the nutritional status, immune status and breeds of the birds.

${ }^{*}$ Corresponding author's e-mail address: alim_bau@yahoo.co.in 


\section{J. Ara and others}

In field condition, birds usually get NDV infection through natural routes like intraocular (IO), intranasal (IN) and oral route. Initially after entrance into host's body, multiplication of the virus occurs at entrance site. Then the viruses enter into the blood and distribute themselves to the different target organs and multiply there (Li and Hanson, 1989). In case of IM or SC routes of inoculation, the viruses initially multiply at the site and then enter into the blood stream to be distributed to the target organs. If viruses are injected intravenously, it is assumed that they will be distributed easily to the target organs very rapidly compared to that of IM or SC routes of inoculation. There are no reports in Bangladesh regarding in vivo distribution of NDV in different tissues of birds after infection through different routes. So, it is important to know how fast viruses are distributed throughout the body following natural and parenteral routes of infection. This paper describes the in-vivo growth kinetics i.e., distribution of virulent NDV in different organs of broiler chickens following experimental infection through different routes.

\section{MATERIALS AND METHODS}

\section{Broiler birds}

A total of 105 day-old-broiler chicks of Cobb 500 were obtained from C.P. Bangladesh Co. Ltd., Dhaka and maintained in the experimental animal shed of the Department of Microbiology and Hygiene, BAU, Mymensingh with strict biosecurity.

\section{Reference viruses}

Neurotropic virulent Newcastle disease virus (NVNDV) was obtained from the repository of the Department of Microbiology and Hygiene, BAU, Mymensingh. This virus was used for experimental infection and as positive control in haemagglutination (HA) and haemagglutination inhibition (HI) tests.

\section{Fertile hen eggs}

Fertile hen eggs with a good hatching rate (95-98\%) were collected from Poultry Farm of FnF Pharmaceuticals Ltd., Jhenaidah. The eggs were incubated at $37^{\circ} \mathrm{C}$ in an egg incubator of the Department of Microbiology and Hygiene maintaining relative humidity of $85 \%$ for 10 days. The well developed healthy embryos were used for the propagation of reference NVNDV as well as various tissue samples of birds of different experimental groups for the isolation of NDV, to determine $\mathrm{ELD}_{50}$ of reference NVNDV and also for preparation of chicken embryo fibroblast $(\mathrm{CEF})$ cell culture.

\section{Experimental infection in broiler chickens with reference NVNDV}

All the broiler chicks (105) were divided into four groups named as A, B, C and D. Each group except group D consists of 30 chicks. Further, chicks of groups A, B and C were equally sub-divided into six sub-groups based on the natural (intranasal, intraocular and oral) and parenteral (intravenous, intramuscular and subcutaneous) routes of infection. All the chicks of group A were experimentally infected at day 7 of age, chicks of group B at day 15 of age and group $\mathrm{C}$ at day 28 of age. Each bird of all sub-groups was received $0.2 \mathrm{ml}$ of NVNDV (300 $\mathrm{ELD}_{50} /$ bird). The group D containing 15 chicks served as non-infected control.

Rectal temperature and clinical signs manifested by the birds of infected groups were recorded daily until death after experimental infection with NVNDV. One bird from each sub-group was subjected to post-mortem examination daily after infection. And various tissue samples (brain, lungs, kidney, spleen, bursa, colon and thymus) and faces were collected for isolation of NDV.

\section{Collection of blood samples to determine MDA before and after infection}

Blood samples were collected from birds of groups A, B, C and D (control) on day 6, 14 and 27 respectively before infection and daily after infection up to day 5 of PI. Sera were separated and subjected to HI test to determine the titre against NDV (Reed and Muench, 1938).

\section{Inoculation of samples into avian embryos}

The inoculum was prepared from all the samples and inoculated into ten-day-old embryonated hen eggs. The embryos died within 24 hours of incubation were discarded and those died after 24 hours of inoculation were chilled at $4{ }^{\circ} \mathrm{C}$ for 2 to 4 hours and then the clear allantoic fluid was carefully collected. All the collected AF were subjected to plate haemagglutination and microplate HA tests following the procedure of Reed and Muench (1938). 


\section{Isolation of virus using CEF cell culture}

The 9-day-old healthy avian embryos were taken for cell culture. The bodies of embryos without head, viscera and appendages were chopped and washed 2-3 times with PBS. Two percent trypsin was added for 15 minutes to trypsinize the tissues. Then the cells were washed three times with PBS. Cells were transferred in culture bottle containing growth promoting media and incubated at $37^{\circ} \mathrm{C}$ for 48 hours to observe confluent growth of cells. The confluent monolayer was allowed to infect with $0.2 \mathrm{ml}$ of inoculum prepared from NDV suspected tissue suspension and kept at $37^{\circ} \mathrm{C}$ for $45-60$ minutes for the establishment of better attachment of the viruses to the cells.

\section{Statistical analysis}

Analysis of variance (One way and two way) was performed to find out the significant differences among the data obtained from experimental infection in different groups of birds where applicable using Statistical Package for Social Sciences (SPSS) Version 13.0 for Windows (Coakes et al., 2006).

\section{RESULTS AND DISCUSSION}

In the present study, following infection through natural routes (IN, IO and oral) with NVNDV, most of the birds of different experimental groups showed high rise of body temperature $\left(\geq 108^{0} \mathrm{~F}\right)$ up to 72 hours of postinoculation (PI) while the birds those were inoculated parenterally showed high body temperature up to 48 hours of PI. The usual phenomenon is that following infection, there is viral replication in the body of the chickens and subsequently results in viraemia and increased levels of viral pyrogens and elevated rectal temperature thereafter (Kouwenhoven, 1993; Robertshaw, 2005). Oladele et al. (2005) recorded high body temperature of bird of different experimental groups up to day 5 of PI. Declination in body temperature was noticed after $72-96$ hours of PI in case of natural routes and 48 hours of PI in case of parenteral routes and subsequently a subnormal temperature $\left(99.4^{0} \mathrm{~F}\right)$ recorded prior to death in this study. Finding of the present study supports the results of Haque (2007) who stated that body temperature became subnormal before death due to diarrhea and dehydration.

Clinical signs recorded in this study were high rise of body temperature, loss of appetite, aggregation of birds, drowsiness, diarrhoea, respiratory distress, paralysis of legs and wings and head shaking which correspond with the findings of Alexander (1997) and Wakamatsu et al. (2006). Appearance of all most all the clinical sings manifested by the birds of groups A (inoculated at 7 days of age) and B (inoculated at 15 days of age) were observed within 72-96 hours of PI in case of natural routes and within 48-72 hours of PI in case of parenteral routes of infection. However, the birds of group $\mathrm{C}$ inoculated at 28 days of age showed clinical signs earlier i.e. within 48 hours of PI following infection through natural routes and within 24 hours of PI following infection through parenteral routes. Early onset of clinical signs by the birds of group $\mathrm{C}$ may be due to absence of maternally derived antibody (MDA) at the time of infection. The nervous signs such as paralysis of legs and wings were observed at day 5 in case of natural routes and day 3 in case of parenteral routes of PI in the birds of all the three groups (A, B and C) which supports the earlier observation of Hamid et al. (1991).

The mean death time differed significantly $(p<0.01)$ between the different natural and parenteral routes of infection (Table 1). However, no significant variation was observed between oral and intraocular routes of infection. Among the three natural and three parenteral routes of infection, the shortest mean death time was recorded in IV inoculated birds of each group (group A: $42.4 \pm 10.2 \mathrm{hr}$, group B: $38.8 \pm 8.9 \mathrm{hr}$ and group C: $37.4 \pm 8.1 \mathrm{hr}$ (Table 1). The shortest duration of mean death time in case of IV route of inoculation may be due to the direct inoculation of virus into the blood stream, which resulted in rapid distribution of virus in different organs and enhanced cell-virus interaction at tissue level thereafter. On the other hand, results of longest duration of mean death time in case of oral route of inoculation are in close agreement with the findings of Okaoye et al. (2001) and Haque (2007) who noticed death of birds within 4-6 days following infection with NDV through natural routes of infection.

Regardless of routes of infection, the significant $(p<0.01)$ variation was found in mean death time between the three groups of birds those were inoculated at different ages. The shortest duration of death time (26-96 hours of PI) was recorded in birds those were inoculated at 28 days of age (group C) and the longest duration of death time (30-132 hours of PI) was recorded in birds inoculated at 7 days of age (group A) (Table 1). This variation in death time may be due to the effect of MDA remained in the blood of the birds at the time of infection (Alexander, 1997). 


\section{J. Ara and others}

Table 1. Mean death time in three groups of broiler birds following experimental infection with NVNDV through natural and parenteral routes

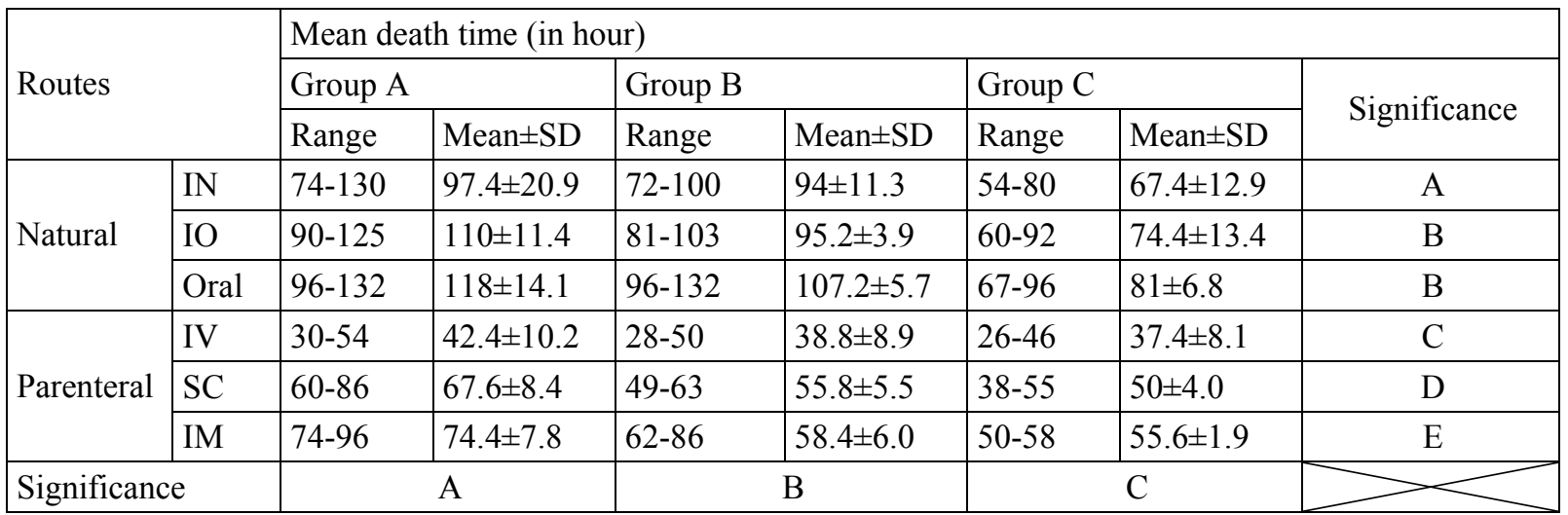

$\mathrm{IO}=$ Intraocular, IN = Intranasal, IV = Intravenous, IM = Intramuscular, SC = Subcutaneous, SD = Standard deviation, Group $\mathrm{A}=$ Birds inoculated at 7 days of age, Group B $=$ Birds inoculated at 15 days of age, Group C = Birds inoculated at 28 days of age. Different lettering in the $9^{\text {th }}$ column indicates overall significant $(\mathrm{p}<0.01)$ differences between the corresponding routes of inoculation regardless of age at inoculation. Different lettering in the $10^{\text {th }}$ row indicates overall significant $(\mathrm{p}<0.01)$ differences between the groups regardless of routes of inoculation.

Table 2. Day-wise isolation of virus from different organs of broiler birds following experimental infection with NVNDV through natural routes using avian embryo

\begin{tabular}{|c|c|c|c|c|c|c|c|c|c|c|c|c|c|c|c|c|}
\hline \multirow{2}{*}{ Group } & \multirow{3}{*}{ Organs } & \multicolumn{15}{|c|}{ Routes } \\
\hline & & \multicolumn{5}{|c|}{ Intranasal } & \multicolumn{5}{|c|}{ Intraocular } & \multicolumn{5}{|l|}{ Oral } \\
\hline \multirow{9}{*}{ A } & & D-1 & D-2 & D-3 & D-4 & D-5 & D-1 & D-2 & D-3 & D-4 & D-5 & D-1 & D-2 & D-3 & D-4 & D-5 \\
\hline & Brain & - & - & - & ++ & ++ & - & - & - & ++ & ++ & - & - & - & ++ & ++ \\
\hline & \begin{tabular}{|l} 
Lungs \\
\end{tabular} & - & - & - & ++ & ++ & - & - & - & + & ++ & - & - & - & ++ & ++ \\
\hline & Kidney & - & - & - & + & + & - & - & - & + & + & - & - & - & + & ++ \\
\hline & Colon & - & - & - & + & + & - & - & - & + & + & - & - & - & + & + \\
\hline & Bursa & - & - & - & ++ & ++ & - & - & - & + & ++ & - & - & - & ++ & ++ \\
\hline & Spleen & - & - & - & + & ++ & - & - & - & + & ++ & - & - & - & + & ++ \\
\hline & Thymus & - & - & - & + & + & - & - & - & + & ++ & - & - & - & + & + \\
\hline & Feces & - & - & - & - & + & - & - & - & - & + & - & - & - & + & ++ \\
\hline \multirow{8}{*}{ B } & Brain & - & - & - & ++ & +++ & - & - & - & ++ & +++ & - & - & - & ++ & +++ \\
\hline & Lungs & - & - & - & ++ & ++ & - & - & - & ++ & ++ & - & - & + & ++ & ++ \\
\hline & Kidney & - & - & - & ++ & ++ & - & - & - & + & ++ & - & - & + & ++ & ++ \\
\hline & Colon & - & - & - & + & ++ & - & - & - & + & ++ & - & - & - & + & ++ \\
\hline & Bursa & - & - & - & ++ & ++ & - & - & - & ++ & ++ & - & - & - & ++ & ++ \\
\hline & Spleen & - & - & - & ++ & ++ & - & - & - & ++ & ++ & - & - & - & + & ++ \\
\hline & \begin{tabular}{|l|} 
Thymus \\
\end{tabular} & - & - & - & + & ++ & - & - & - & + & ++ & - & - & - & + & + \\
\hline & Feces & - & - & - & + & ++ & - & - & - & + & + & - & - & - & + & ++ \\
\hline \multirow{8}{*}{$\mathrm{C}$} & Brain & - & - & +++ & +++ & $x$ & - & - & ++ & +++ & $x$ & - & - & +++ & +++ & $x$ \\
\hline & \begin{tabular}{|l|} 
Lungs \\
\end{tabular} & - & + & ++ & +++ & $\times$ & - & ++ & ++ & ++ & $x$ & - & + & ++ & +++ & $x$ \\
\hline & Kidney & - & + & ++ & ++ & $x$ & - & + & ++ & ++ & $x$ & - & ++ & ++ & ++ & $x$ \\
\hline & Colon & - & + & + & ++ & $x$ & - & - & + & ++ & $x$ & - & - & + & ++ & $x$ \\
\hline & Bursa & - & - & + & ++ & $x$ & - & - & ++ & ++ & $x$ & - & - & ++ & ++ & $x$ \\
\hline & Spleen & - & - & + & ++ & $x$ & - & - & ++ & ++ & $x$ & - & - & ++ & ++ & $x$ \\
\hline & \begin{tabular}{|l|} 
Thymus \\
\end{tabular} & - & - & + & ++ & $x$ & - & - & + & ++ & $x$ & - & - & + & ++ & $x$ \\
\hline & Feces & - & - & + & ++ & $x$ & - & - & + & + & $x$ & - & - & ++ & ++ & $x$ \\
\hline
\end{tabular}

- = no virus isolation, $+=$ HA titre (64-128), $++=$ HA titre (256-512), $+++=$ HA titre (1024-2048), $x=$ Death of birds, A $=$ Birds inoculated at 7 days of age, $\mathrm{B}=$ Birds inoculated at 15 days of age, $\mathrm{C}=$ Birds inoculated at 28 days of age, $\mathrm{D}=$ Days. 
Following infection through natural routes (IN, IO and oral), all the tissue samples (brain, lungs, colon, kidney, bursa, spleen and thymus) and faeces collected at day 4 of PI and onward from birds of groups A (inoculated at 7 days of age) and B (inoculated at 15 days of age) and day 3 to onward of PI from birds of group C (inoculated at 28 days of age) were positive for virus isolation (Table 2). However, isolation of NDV was possible from some tissue samples (lungs, kidney and colon) collected at day 2 of PI from group C. These findings of the present study strongly support the findings of Wakamatsu et al. (2006) who isolated NDV from brain, lung, kidney, bursa, spleen and thymus within 3-5 days of PI through oral route. Haque (2007) also isolated NDV from spleen, lungs, colon and brain within 3-4 days of PI through natural routes of inoculation.

In case of parenteral routes (IV, IM and SC), isolation of NDV was positive from faeces and all other tissue samples (brain, lungs, colon, kidney, bursa, spleen and thymus) those were collected at day 2 of PI and onward from birds of all the three groups except the samples collected from birds of group A inoculated through SC and IM route of inoculation (Table 3). Hamid et al. (1991) isolated NDV from lungs, brain, spleen and bursa within 25 days of PI through IM route which strongly supports the findings of the present study of virus isolation after infection through IM route. Isolation of NDV was not possible from various tissue samples collected at day 1 of PI even from parenterally inoculated birds except brain, lungs and kidney of birds inoculated intravenously at 28 days of age.

Table 3. Day-wise isolation of virus from different organs of broiler birds following experimental infection with NVNDV through parenteral routes using avian embryo

\begin{tabular}{|c|c|c|c|c|c|c|c|c|c|c|c|c|c|c|c|c|}
\hline \multirow{2}{*}{ Group } & \multirow{3}{*}{ Organs } & \multicolumn{15}{|c|}{ Routes } \\
\hline & & \multicolumn{5}{|c|}{ Intravenous } & \multicolumn{5}{|c|}{ Subcutaneous } & \multicolumn{5}{|c|}{ Intramuscular } \\
\hline \multirow{9}{*}{ A } & & D-1 & D-2 & D-3 & $\mathrm{D}-4$ & D-5 & D-1 & $\mathrm{D}-2$ & D-3 & D-4 & D-5 & D-1 & D-2 & D-3 & D-4 & D-5 \\
\hline & Brain & - & ++ & ++ & $x$ & $x$ & - & - & ++ & ++ & $x$ & - & - & ++ & ++ & $x$ \\
\hline & Lungs & - & ++ & ++ & $x$ & $x$ & - & - & + & ++ & $x$ & - & - & ++ & ++ & $x$ \\
\hline & Kidney & - & + & ++ & $\times$ & $x$ & - & - & + & + & $x$ & - & - & ++ & ++ & $x$ \\
\hline & Colon & - & + & ++ & $x$ & $x$ & - & - & + & ++ & $x$ & - & - & + & ++ & $x$ \\
\hline & Bursa & - & ++ & ++ & $x$ & $x$ & - & - & ++ & ++ & $x$ & - & - & ++ & ++ & $x$ \\
\hline & Spleen & - & + & ++ & $x$ & $x$ & - & - & + & ++ & $x$ & - & - & + & + & $x$ \\
\hline & Thymus & - & + & ++ & $x$ & $x$ & - & - & + & ++ & $x$ & - & - & + & + & $x$ \\
\hline & Feces & - & + & ++ & $x$ & $x$ & - & - & + & ++ & $x$ & - & - & - & + & $x$ \\
\hline \multirow{8}{*}{ B } & Brain & - & ++ & +++ & $x$ & $x$ & - & ++ & +++ & $\times$ & $x$ & - & +++ & +++ & $x$ & $x$ \\
\hline & Lungs & - & ++ & ++ & $x$ & $x$ & - & ++ & ++ & $x$ & $x$ & - & ++ & ++ & $x$ & $x$ \\
\hline & Kidney & - & ++ & ++ & $x$ & $x$ & - & + & ++ & $x$ & $x$ & - & ++ & ++ & $x$ & $x$ \\
\hline & Colon & - & + & ++ & $x$ & $\times$ & - & + & + & $\times$ & $x$ & - & + & + & $x$ & $x$ \\
\hline & Bursa & - & ++ & ++ & $x$ & $x$ & - & ++ & ++ & $x$ & $x$ & - & + & ++ & $x$ & $x$ \\
\hline & Spleen & - & + & ++ & $x$ & $x$ & - & + & ++ & $x$ & $x$ & - & ++ & ++ & $x$ & $x$ \\
\hline & Thymus & - & + & ++ & $\times$ & $x$ & - & + & ++ & $x$ & $\times$ & - & + & + & $x$ & $x$ \\
\hline & Feces & - & - & + & $x$ & $\times$ & - & + & ++ & $x$ & $\times$ & - & + & + & $x$ & $x$ \\
\hline \multirow{8}{*}{$\mathrm{C}$} & Brain & ++ & +++ & $x$ & $x$ & $x$ & - & +++ & +++ & $x$ & $x$ & - & +++ & +++ & $x$ & $x$ \\
\hline & Lungs & + & +++ & $x$ & $x$ & $x$ & - & ++ & +++ & $x$ & $x$ & - & ++ & ++ & $\times$ & $\times$ \\
\hline & Kidney & + & ++ & $x$ & $x$ & $x$ & - & ++ & ++ & $x$ & $x$ & - & ++ & ++ & $x$ & $x$ \\
\hline & Colon & - & ++ & $x$ & $x$ & $x$ & - & + & ++ & $x$ & $x$ & - & + & ++ & $x$ & $x$ \\
\hline & Bursa & - & ++ & $x$ & $x$ & $x$ & - & ++ & ++ & $x$ & $x$ & - & ++ & ++ & $x$ & $x$ \\
\hline & Spleen & - & ++ & $x$ & $x$ & $x$ & - & ++ & ++ & $x$ & $x$ & - & ++ & ++ & $x$ & $x$ \\
\hline & Thymus & - & ++ & $x$ & $x$ & $x$ & - & + & ++ & $x$ & $x$ & - & ++ & ++ & $x$ & $x$ \\
\hline & Feces & - & + & $x$ & $x$ & $x$ & - & + & ++ & $x$ & $x$ & - & + & ++ & $x$ & $x$ \\
\hline
\end{tabular}

$-=$ no virus isolation, $+=$ HA titre (64-128), $++=$ HA titre $(256-512),+++=$ HA titre $(1024-2048), \times=$ Death of birds, A $=$ Birds inoculated at 7 days of age, $\mathrm{B}=$ Birds inoculated at 15 days of age, $\mathrm{C}=$ Birds inoculated at 28 days of age, $\mathrm{D}=\mathrm{Days}$.

All the five samples those were positive for isolation of virus in avian embryo were also positive for isolation of viruses in CEF cell culture. Again, among the 5 samples those were negative for virus isolation in avian embryo, three of them were positive for isolation of viruses in CEF cell culture. The rate of virus isolation in CEF culture 


\section{J. Ara and others}

indicated that CEF cell culture is superior for isolation of NDV to that in avian embryos. This finding is in agreement with the observation of Alexander (1997) and Roy and Vanugopalan (1999). However, the rate of virus isolation could be increased if these samples were inoculated in SPF eggs in this study (Haque, 2007). The cytopathic effects (Figs. 3-6) such as rounding and clumping of the cells, formation of syncytium, presence of ghost cells and desquamation of cells observed in this study were similar to the findings of Miah et al. (2006).

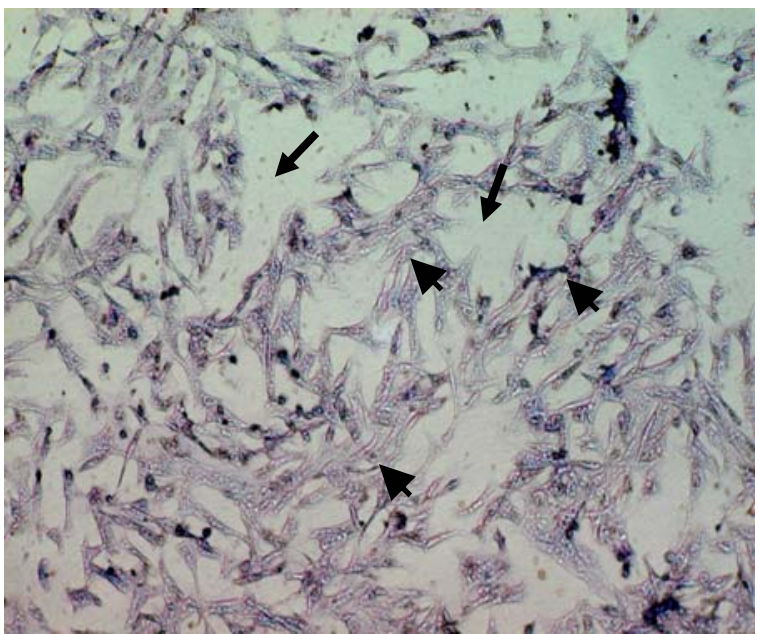

Fig. 1. NDV infected CEF cells showing different type of CPE at day 2 of post-infection isolated from brain (x10). Desquamation of cells (arrow), syncytium formation (arrow head).

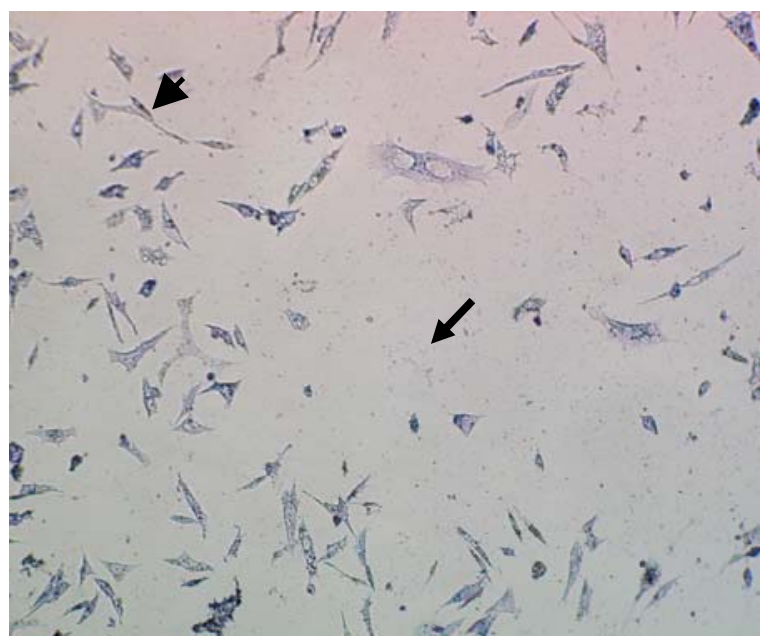

Fig. 3. NDV infected CEF cells showing different type of CPE at day 4 of post-infection isolated from lungs (x10). Desquamation of cells (arrow), elongation of cells (arrow head).

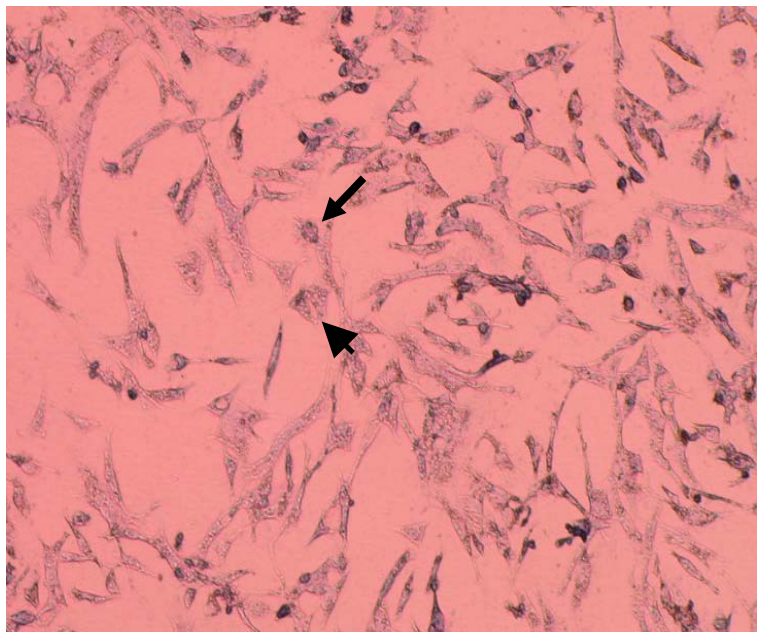

Fig. 2. NDV infected CEF cells showing different type of CPE at day 3 of post-infection isolated from lungs (x10). Rounding of cells (arrow), cytoplasm containing granules (arrow head).

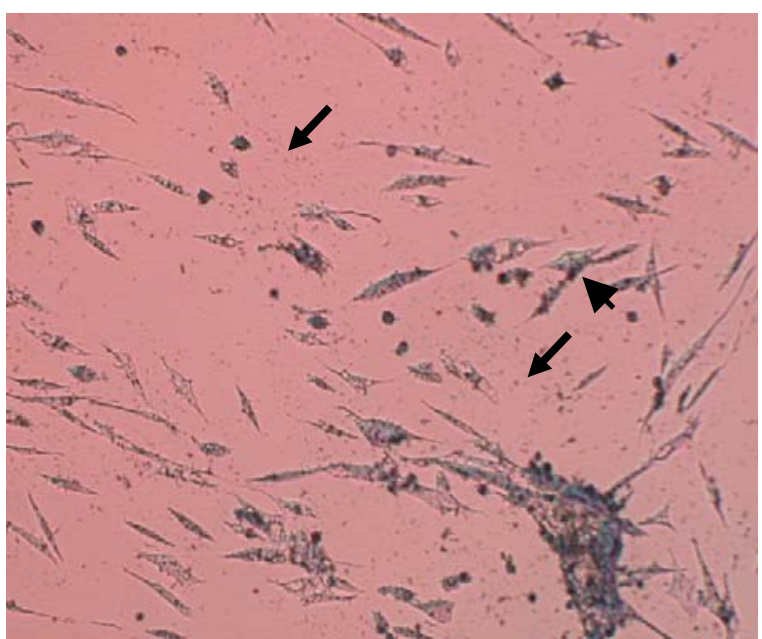

Fig. 4. NDV infected CEF cells showing different type CPE at day 5 post-infection isolated from lungs (X10). Desquamation of cells (arrow), Formation of giant cells (arrow head).

Of the three parenteral routes of infection (IV, IM and SC), significantly $(p<0.01)$ higher HA titre of NDV isolates was recorded in IV route of infection and of the three natural routes of infection (IN, IO and oral), the HA titre of isolated NDV was significantly $(\mathrm{p}<0.01)$ higher in IN route of infection compared to those of IO and oral routes of infection (Table 4). It may be assumed that, following inoculation through IV route, viruses directly enter into the circulation and subsequently distribute to different organs at faster rate (Flint et al., 2004). 
Of the various tissue samples, the highest titre of isolated NDV was found in allantoic fluid (AF) collected from the embryos inoculated with brain tissue followed by lungs and kidney respectively. As the NDV was neurotropic in nature, there might have more multiplication of virus in brain tissue (Wilczynski et al., 1977; Banerjee et al., 1994). However, results of higher HA titre of NDV in lungs and kidney is consistent with the findings of Hamid et al. (1991).

Table 4. Haemagglutination (HA) titre of isolated NDV from different organs of broiler birds following experimental infection with NVNDV through different routes

\begin{tabular}{|c|c|c|c|c|c|c|c|}
\hline \multirow[t]{2}{*}{ Route } & \multirow[t]{2}{*}{ Groups } & \multicolumn{5}{|c|}{ HA titre of isolated NDV } & \multirow[t]{2}{*}{ Significance } \\
\hline & & Day 1 & Day 2 & Day 3 & Day 4 & Day 5 & \\
\hline \multirow[t]{3}{*}{ IN } & A & - & - & - & \begin{tabular}{|l|}
$128-256$ \\
$182.9 \pm 68.4$
\end{tabular} & $\begin{array}{l}128-512 \\
272 \pm 159.5\end{array}$ & \multirow{3}{*}{ A } \\
\hline & $\mathrm{B}$ & - & - & - & $\begin{array}{l}128-512 \\
272 \pm 159.5\end{array}$ & $\begin{array}{l}256-1024 \\
416 \pm 271.5\end{array}$ & \\
\hline & $\mathrm{C}$ & - & $\begin{array}{l}64-128 \\
106.6 \pm 37\end{array}$ & $\begin{array}{l}64-512 \\
248 \pm 175.8\end{array}$ & \begin{tabular}{|l|}
$256-1024$ \\
$576 \pm 319.1$
\end{tabular} & $x$ & \\
\hline \multirow[t]{3}{*}{$\mathrm{IO}$} & $\mathrm{A}$ & - & - & - & \begin{tabular}{|l|}
$64-256$ \\
$137.14 \pm 57.5$
\end{tabular} & $\begin{array}{l}128-512 \\
224 \pm 132.5\end{array}$ & \multirow{3}{*}{$\mathrm{AB}$} \\
\hline & $\mathrm{B}$ & - & - & $\begin{array}{l}64-512 \\
200 \pm 142.8\end{array}$ & $\begin{array}{l}128-1024 \\
400 \pm 285.7\end{array}$ & $x$ & \\
\hline & $\mathrm{C}$ & - & \begin{tabular}{|l|}
$64-256$ \\
$144 \pm 80.5$
\end{tabular} & \begin{tabular}{|l|}
$128-512$ \\
$347.4 \pm 160.4$
\end{tabular} & \begin{tabular}{|l|}
$256-1024$ \\
$544 \pm 298.2$ \\
\end{tabular} & $x$ & \\
\hline \multirow[t]{3}{*}{ Oral } & A & - & - & - & \begin{tabular}{|l|}
$64-256$ \\
$120 \pm 63.4$
\end{tabular} & $\begin{array}{l}128-512 \\
224 \pm 132.5\end{array}$ & \multirow{3}{*}{ B } \\
\hline & B & - & - & - & $\begin{array}{l}128-512 \\
224 \pm 132.5\end{array}$ & $\begin{array}{l}128-1024 \\
432 \pm 281.6\end{array}$ & \\
\hline & $\mathrm{C}$ & - & \begin{tabular}{|l|}
$64-256$ \\
$149.3 \pm 97.8$
\end{tabular} & \begin{tabular}{|l|}
$128-512$ \\
$310.8 \pm 145.1$
\end{tabular} & \begin{tabular}{|l|}
$256-1024$ \\
$544 \pm 319.1$
\end{tabular} & $x$ & \\
\hline \multirow[t]{3}{*}{ IV } & A & - & \begin{tabular}{|l|}
$128-512$ \\
$240 \pm 126.8$
\end{tabular} & $\begin{array}{l}128-512 \\
384 \pm 181.0\end{array}$ & $x$ & $x$ & \multirow{3}{*}{$\mathrm{C}$} \\
\hline & $\mathrm{B}$ & - & \begin{tabular}{|l|}
$128-512$ \\
$256 \pm 181.0$
\end{tabular} & \begin{tabular}{|l|}
$256-512$ \\
$384 \pm 136.8$ \\
\end{tabular} & $x$ & $x$ & \\
\hline & $\mathrm{C}$ & $\begin{array}{l}256-512 \\
426.6 \pm 147.8\end{array}$ & \begin{tabular}{|l|}
$256-1024$ \\
$640 \pm 335.1$ \\
\end{tabular} & $x$ & $x$ & $x$ & \\
\hline \multirow[t]{3}{*}{$\mathrm{SC}$} & A & - & - & \begin{tabular}{|l|}
$64-512$ \\
$192 \pm 149.1$
\end{tabular} & $\begin{array}{l}128-512 \\
288 \pm 149.1\end{array}$ & - & \multirow{3}{*}{$\mathrm{D}$} \\
\hline & $\mathrm{B}$ & - & \begin{tabular}{|l|}
$64-512$ \\
$248 \pm 175.8$
\end{tabular} & \begin{tabular}{|l|}
$128-1024$ \\
$384 \pm 198.2$
\end{tabular} & $x$ & $x$ & \\
\hline & $\mathrm{C}$ & - & \begin{tabular}{|l|}
$128-512$ \\
$288 \pm 149.2$
\end{tabular} & $\begin{array}{l}256-1024 \\
544 \pm 319.1\end{array}$ & $x$ & $\times$ & \\
\hline \multirow[t]{3}{*}{ IM } & A & - & - & \begin{tabular}{|l|}
$64-512$ \\
$168 \pm 152.8$
\end{tabular} & \begin{tabular}{|l}
$64-512$ \\
$264 \pm 196.2$
\end{tabular} & $x$ & \multirow{3}{*}{$\mathrm{D}$} \\
\hline & $\mathrm{B}$ & - & \begin{tabular}{|l|}
$64-256$ \\
$160 \pm 78.9$
\end{tabular} & \begin{tabular}{|l|}
$128-1024$ \\
$384 \pm 198.2$ \\
\end{tabular} & $x$ & & \\
\hline & $\mathrm{C}$ & - & \begin{tabular}{|l|}
$64-256$ \\
$144 \pm 80.5$
\end{tabular} & \begin{tabular}{|l}
$256-1024$ \\
$544 \pm 319.1$
\end{tabular} & $x$ & & \\
\hline \multicolumn{2}{|c|}{ Significance } & $\mathrm{A}$ & $\mathrm{B}$ & $\mathrm{C}$ & $\mathrm{D}$ & $\mathrm{D}$ & \\
\hline
\end{tabular}

$\mathrm{A}=$ Birds inoculated at 7 days of age, $\mathrm{B}=$ Birds inoculated at 15 days of age, $\mathrm{C}=$ Birds inoculated at 28 days of age, $\mathrm{IO}=$ Intraocular, IN = Intranasal, IV = Intravenous, IM = Intramuscular, SC = Subcutaneous, ${ }^{\mathrm{a}}$ Range, ${ }^{\mathrm{b}} \mathrm{Mean} \pm$ Standard deviation, - = No HA titre,$x=$ Death of all birds. Values bearing same letter within the same row and same column differ significantly $(\mathrm{p}<0.01)$. 


\section{J. Ara and others}

Table 5. Correlation between serum antibody titre and ND virus titre in three groups of broiler birds after experimental infection with NVNDV through natural and parenteral routes

\begin{tabular}{|c|c|c|c|c|c|c|c|c|c|c|c|c|}
\hline \multirow{2}{*}{\multicolumn{2}{|c|}{$\begin{array}{l}\text { Route/ } \\
\text { Group }\end{array}$}} & \multirow{2}{*}{$\begin{array}{l}\text { Ab titre } \\
\text { before } \\
\text { infection }\end{array}$} & \multicolumn{2}{|c|}{ Day 1} & \multicolumn{2}{|c|}{ Day 2} & \multicolumn{2}{|c|}{ Day 3} & \multicolumn{2}{|c|}{ Day 4} & \multicolumn{2}{|c|}{ Day 5} \\
\hline & & & $\begin{array}{l}\mathrm{Ab} \\
\text { titre }\end{array}$ & $\begin{array}{l}\text { Virus } \\
\text { titre }\end{array}$ & $\begin{array}{l}\mathrm{Ab} \\
\text { titre }\end{array}$ & $\begin{array}{l}\text { Virus } \\
\text { titre }\end{array}$ & $\begin{array}{l}\mathrm{Ab} \\
\text { titre }\end{array}$ & $\begin{array}{l}\text { Virus } \\
\text { titre }\end{array}$ & $\begin{array}{l}\mathrm{Ab} \\
\text { titre }\end{array}$ & $\begin{array}{l}\text { Virus } \\
\text { titre }\end{array}$ & $\begin{array}{l}\mathrm{Ab} \\
\text { titre }\end{array}$ & $\begin{array}{l}\text { Virus } \\
\text { titre }\end{array}$ \\
\hline \multirow[t]{3}{*}{ IN } & A & 32 & 16 & - & 16 & - & 8 & - & $\leq 4$ & 182.9 & $\leq 4$ & 272 \\
\hline & $\mathrm{B}$ & 16 & 16 & - & 8 & - & $\leq 4$ & - & $\leq 4$ & 272 & $\leq 4$ & 416 \\
\hline & $\mathrm{C}$ & $\leq 4$ & $\leq 4$ & - & $\leq 4$ & 106.6 & $\leq 4$ & 248 & $\leq 4$ & 576 & $x$ & $x$ \\
\hline \multirow[t]{3}{*}{$\mathrm{IO}$} & A & 32 & 32 & - & 32 & - & 8 & - & $\leq 4$ & 137.14 & $\leq 4$ & 224 \\
\hline & $\mathrm{B}$ & 16 & 8 & - & 8 & - & $\leq 4$ & 200 & $\leq 4$ & 400 & $\times$ & $x$ \\
\hline & $\mathrm{C}$ & $\leq 4$ & $\leq 4$ & - & $\leq 4$ & 144 & $\leq 4$ & 347.4 & $x$ & 544 & $\times$ & $x$ \\
\hline \multirow[t]{3}{*}{ Oral } & $\mathrm{A}$ & 32 & 64 & - & 32 & - & 16 & - & 8 & 120 & $\leq 4$ & 224 \\
\hline & $\mathrm{B}$ & 16 & 16 & - & 8 & - & 8 & - & $\leq 4$ & 224 & $\leq 4$ & 432 \\
\hline & $\mathrm{C}$ & $\leq 4$ & $\leq 4$ & - & $\leq 4$ & 149.3 & $\leq 4$ & 310.8 & $\leq 4$ & 544 & $x$ & $x$ \\
\hline \multirow[t]{3}{*}{ IV } & A & 32 & 32 & - & 8 & 240 & $\leq 4$ & 384 & $x$ & $x$ & $x$ & $x$ \\
\hline & $\mathrm{B}$ & 16 & 16 & - & 8 & 256 & $\leq 4$ & 384 & $\times$ & $\times$ & $\times$ & $\times$ \\
\hline & $\mathrm{C}$ & $\leq 4$ & $\leq 4$ & 426.6 & $\leq 4$ & 640 & $x$ & $x$ & $x$ & $x$ & $x$ & $x$ \\
\hline \multirow[t]{3}{*}{$\mathrm{SC}$} & A & 32 & 16 & - & 16 & - & 8 & 192 & $\leq 4$ & 288 & $x$ & $x$ \\
\hline & $\mathrm{B}$ & 16 & 16 & - & 8 & 248 & $\leq 4$ & 384 & $x$ & $x$ & $x$ & $x$ \\
\hline & $\mathrm{C}$ & $\leq 4$ & $\leq 4$ & - & $\leq 4$ & 288 & $\leq 4$ & 544 & $x$ & $x$ & $\times$ & $x$ \\
\hline \multirow[t]{3}{*}{ IM } & A & 32 & 32 & - & 16 & - & 8 & 168 & 8 & 264 & - & $x$ \\
\hline & B & 16 & 16 & - & 8 & 160 & $\leq 4$ & 384 & $x$ & $x$ & $x$ & $x$ \\
\hline & $\mathrm{C}$ & $\leq 4$ & $\leq 4$ & - & $\leq 4$ & 144 & $\leq 4$ & 544 & $\times$ & $\times$ & $\times$ & $x$ \\
\hline \multirow[t]{3}{*}{ Control } & $\mathrm{A}$ & 32 & 32 & - & 32 & - & 16 & - & 8 & - & $\leq 4$ & - \\
\hline & $\mathrm{B}$ & 16 & 16 & - & 16 & - & 8 & - & 8 & - & $\leq 4$ & - \\
\hline & $\mathrm{C}$ & $\leq 4$ & $\leq 4$ & - & $\leq 4$ & - & $\leq 4$ & - & $\leq 4$ & - & $\leq 4$ & - \\
\hline
\end{tabular}

- = No virus isolation, $\times=$ Death of birds, $\mathrm{IO}=$ Intraocular, $\mathrm{IN}=$ Intranasal, $\mathrm{IV}=$ Intravenous, $\mathrm{IM}=\mathrm{Intramuscular}, \mathrm{SC}=$ Subcutaneous, $\mathrm{A}=$ Birds inoculated at 7 days of age, $\mathrm{B}=$ Birds inoculated at 15 days of age, $\mathrm{C}=$ Birds inoculated at 28 days of age, $\mathrm{Ab}=$ Antibody.

Following experimental infection with NVNDV through six different routes (IN, IO, Oral, IV, IM and SC), the MDA titres decreased day by day in the birds of different experimental groups (Table 5). This finding slightly disagree with the findings of Oladele et al. (2005) who found increasing trend of antibody titre after 2 day of PI in case of inoculation of mild virulent NDV in their study. However, it is interesting to note that the MDA titres decreased day by day with the increase of HA titres of NDV from different tissues regardless route of infection incase of broiler birds of different experimental groups.

\section{REFERENCES}

1. Alexander DJ (1997). Newcastle disease and other paramyxoviridae infections. In: Diseases of Poultry, $10^{\text {th }}$ edn., BW Calnek, HJ Barnes, CW Beard, LR McDougald and YM Saif (eds). Iowa State University Press, Ames, USA. pp. 541569.

2. Awan MA, Otte MJ and James MD (1994). The epidemiology of Newcastle disease in rural poultry: a review. Avian Pathology 23: 405-423.

3. Babu SAM (2007). Isolation and Identification of Newcastle disease virus from chicken of suspected avian influenza outbreak of Mymensingh sadar in 2007. An MS thesis submitted to the Department of Microbiology and Hygiene, Faculty of Veterinary Science, Bangladesh Agricultural University, Mymensingh.

4. Banerjee M, Reed WM, Fitzgerald SB and Panigrahy B (1994). Neurotropic velogenic Newcastle disease in cormorants in Michigan: pathology and virus characterization. Avian Diseases 38: 873-878.

5. Coakes SJ, Steed L and Dzidic P (2006). Statistical Package for Social Sciences (SPSS) Version 13.0 for Windows.

6. Flint SJ, Racaniello VR and Skalka AM (2004). Attachment and entry. In: Principles of virology, molecular biology, pathogenesis and control of animal viruses. American Society for Microbiology, Washington, DC. pp. 126-176. 
7. Gutierrez-Ruiz EJ, Ramirez-Cruz GT, Camara-Gamboa EI, Alexander DJ and Gough RE (2000). A serological survey for avian infectous bronchitis virus and Newcastle disease virus antibodies in backyard (free-range) village chickens in Mexico. Tropical Animal Health and Production 32: 381-190.

8. Hamid H, Campbell RS and Parede L (1991). Studies Of the pathology of velogenic Newcastle disease: Virus infection in non-immune and immune birds. Avian Pathology 20 (4): 561-575.

9. Haque H (2007). Isolation and molecular detection of Newcstle disease virus from clinical and post-mortem samples of broiler and layer chickens. An MS thesis submitted to the Department of Microbiology and Hygiene, Faculty of Veterinary Science, Bangladesh Agricultural University, Mymensingh.

10. Kouwenhoven B (1993). Newcastle disease. In: JB McFerran and MS McNulty Series (eds). Viral Infections of Vertebrates. Vol. 3, Elsevier Scientific Publishing Co, Amsterdam. pp. 341-360.

11. Lamb RA, Collins PL, Kolakofsky D, Melero JA, Nagai Y, Oldstore MBA, Pringle CR and Rima BK (2000). Paramyxoviridae: The viruses and their replication. In: MHV van Regenmortel (ed). Virus Taxonomy, Seventh Report of the International Committee on Taxonomy of Viruses. Academic Press, New York. pp. 549-561.

12. Li X and Hanson RP (1989). In vivo interference by Newcastle disease virus in chickens, the natural host of the virus. Archives of Virology 108: 229-245.

13. Liu M, Wang Z, Song C, Wang Y, Yu B, Xheng D, Sun C and Wu Y (2006). Characterization of pigeon-origin Newcastle disease virus isolated in china. Avian Diseases 50: 636-640.

14. Miah MAR, Rahman MM, Khan MSR, Hossain MT and Bhattacharjee J (2006). Adaptation and propagation of Newcastle disease virus in chicken embryo fibroblast cell culture. Journal of Bangladesh Society for Agricultural Science and Technology 3 (3\&4): 165-168.

15. Okaoye JOA, Ife MC and Ikejiaka CN (2001). Effect of post-infection vaccination on mortality associated with velogenic Newcastle disease. Proceeding of the $38^{\text {th }}$ Annual Congress of the Nigerian Veterinary Medical Association, Sokoto, Nigeria. pp. 69-71.

16. Oladele SB, Nok AJ, Esievo KAN, Abdu P and Useh N (2005). Newcastle disease as a model for Paramyxovirus include neurogenic syndromes. American Journal of Pathology 89 (3): 649-660.

17. Reed LJ and Muench H (1938). A simple method of estimating fifty percent end points. American Journal of Hygiene 27: 493-497.

18. Robertshaw D (2005). Temperature regulation and the thermal environment. In: Reece WO (ed), Duke's Physiology of domestic animals. $12^{\text {th }}$ edn., Panima Publishing Corporation, New Delhi. pp. 962-973.

19. Roy P and Venugopalan AT (1999). Velogenic Newcastle disease virus in captive wild birds. Tropical Animal Health and Production 30 (5): 299-303.

20. Wakamatsu N, King DJ, Kapczniski DR, Seal BS and Brown CC (2006). Experimental pathogenesis for chickens, turkeys and pigeons of exotic Newcastle disease virus from an outbreak in California during 2002-2003. Veterinary Pathology 43: 925-933.

21. Wilczynski SP, Cook ML and Stevens JG (1977). Newcastle disease as a model for paramyxovirus-induced neurologic syndromes. II. Detailed characterization of the encephalitis. American Journal of Pathology 89 (3): 649-666. 